\title{
'As Fast as One Possibly Can ...' Virtuosity, a Truth of Musical Performance? ${ }^{1}$
}

\author{
in Critical Musicological Reflections. Essays in Honour of Derek B. Scott
} Stan Hawkins ed. Aldershot: Ashgate, 2011, Chapter 8

\author{
Antoine Hennion \\ MINES ParisTech, CSI - Centre de sociologie de l'innovation, CNRS UMR 7185 \\ 60 bd St-Michel, 75006 Paris, France \\ antoine.hennion@mines-paristech.fr \\ translation: Anne Paterson Farina and Stan Hawkins
}

Virtuosity is a concept that has the double advantage of being transverse with respect to different musical genres and of pointing at performance ${ }^{2}-$ at music that is not fixed by the score. These are two characteristics that directly refer to approaches developed by Derek Scott, which he has done by focusing, as I intend to do, on the nineteenth century - a period when great divides were established. ${ }^{3}$ These divides still govern current musical practices, and perhaps even more, the academic disciplines that target them. In the course of the questioning of the opposition between popular and art music as carried out by critical musicology, ${ }^{4}$ and mirroring its focus on the notion of performance, ${ }^{5}$ I have decided to pay respect to the way musicians themselves have taken on the constitutional ambivalence of virtuosity. Indeed, for them this refers less to the specific property some types of music or artists possess than to a distanced attraction - a dangerous temptation, an impossible injunction of which they need to be wary.

Undoubtedly, virtuosity is part of indigenous musicians' vocabulary - it signifies the height of a musician's skills or the seductive prowess of an illusionist. Used both by specialists and by amateurs, the word is powerful in its critical load, albeit positive or negative: it enables the listener to qualify and disqualify an interpreter, to honour an artist or to despise another. There is the matter of the 'virtuosity-effect', which this use of the word, accusing or laudatory, demonstrates. I would posit that this effect is able to guide us into the domain of the mysterious issues of performance. My contribution to this volume is therefore not an analytical effort to afford virtuosity a musical and sociological definition that would be as definite as possible (and that indeed is what the word definition suggests), nor to

\footnotetext{
${ }^{1}$ A first version of this chapter was published in French in an online journal: http://ateliers revues.org/8764 (Hennion 2011). The chapter has been translated by Anne Paterson Farina and Stan Hawkins.

${ }^{2}$ I note that the English word 'performance' is far more relevant than the French usage, which expresses interpretation, or worse, execution.

${ }^{3}$ Scott $(1989,2008)$

${ }^{4}$ This theme was introduced in the 1980s by scholars, such as J. Kerman and A. Durant, gaining momentum in size and content through an alternative promotion of popular culture (e.g. Leppert and McClary 1987, Frith 1996, Whiteley et al., 2004).

${ }^{5}$ Typically, performance studies are divided because of the dual meaning of the word: a reference to theatre taken as a model of self-expression (Jackson 2004); and the idea of the necessary performativity of a social identity (Schechner 2002). This opposition - 'life as performance' vs. 'performance as life' - seems less an ambiguity that requires resolving than a founding ambivalence that makes the word interesting. All depends on whether one takes theatrical performance just as a case study or, conversely, as Judith Butler did, an interest in performance as the production of oneself or of collectives that, in that way, we allow to exist, we realize, we produce - all the words filled with the same dual meaning, referring both to the world of performance and to a pragmatism of existence and identity (Butler 1997, 2005).
} 
provide it with a sense that is stable and independent of situations: for this is exactly what virtuosity, by playing with boundaries, continually seeks to bypass. It would also be somewhat problematic, considering that virtuosity tries to express just the opposite: to give voice to a sense of instability and the fleeting moment by accepting as a criterion the bliss of a performance as nothing but its radical dependence from the present situation. ${ }^{6}$ While extending the boundaries that separate musical genres, my purpose is rather to question two contrasting definitions of virtuosity that are strongly present in debates and judgments.

On the one hand, virtuosity has been considered rather negatively as a performance aimed at a public that outwardly demonstrates exception agility in terms of instrumental or vocal technique, especially as related to speed of execution. Such displays are both admired as demonstrations of a divine gift and condemned as a diabolical perversion of musical performance. On the other hand, pushing things to their limits is a pressing need in musical practice, which implies that virtuosity is a more complex issue. This involves an internal musical urge from within. It is perceived as a corporeal and risky litmus test of the mysterious power of music and musicians' talents in a way that forces them to extreme points where they not only reveal their drive, but also topple a music event into states whose boundaries are less easy to determine. This refers to states that words are less capable of defining: primary emotion, collective intoxication and moments of trance. ${ }^{7}$

As is evident from this very formulation, these two ways of describing virtuosity are not as contradictory as they might seem. Sorting them out ('virtuosity for its own sake' $v s$. 'virtuosity in the service of a work', to coin a cliché) is easier to do ex post, once a concert has ended, than during the course of performance when the status of what is at stake at the moment is nothing but obvious, nor is the very fact of evaluating whether it is a success or a failure: how, why, and to what end are we to distinguish between the emotion caused by incredible skills and one's fascination with a rare talent, or by that sense of being carried away by a whirlwind of music, an intense 'breakaway' when music finally no longer exists as a score or a 'piece', but rather as an emotion; when it emerges from the moment as a flicker? It is not what is played, but what comes out of fingers and bodies in motion, uncontrolled, the speed and contrasts of which make the material of sound crack, stripping the screen of its notes.

\section{If You Have to Ask What It Is ...}

Theoretically, there is a great difficulty in finding the right register through which to address intermediate words, such as virtuosity (as is the case for words such as 'grace' or 'presence'). They accompany and describe a common experience with which they are familiar. Then, it is impossible to determine whether they help in analysis or whether they are directly involved in its accomplishment. They serve in analysing the phenomenon they refer to, but at the same time they put things in shape, they allow a grasping of it in some way that contributes to bringing it out. Certainly, this applies to all our categories, something ethnomethodology has taught us. However, what is interesting here are not the basics of the way any qualification operation runs. These are not the limits of any effort to put things into words insofar as, partly constituting the reality they are designating, they are reciprocally called to evolve with it. It is the peculiarity of certain odd words, such as virtuosity, that are suggestive but indefinable, resistant to formalization, as if they only made sense through

\footnotetext{
${ }^{6}$ Sudnow (1978).

${ }^{7}$ Rouget (1980).
} 
their own uncertainty and, far from giving them additional weight and efficiency, the effort made to find a more analytical or general basis for these ideas caused them to escape like water in a creek, leaving us void.

Such evanescence - the way in which wear and tear takes its course - is in fact particular in every single case, although it is not necessarily the usual destiny of such musical categories. Instead, many other categories have provided musical performance with a framework that has been reinforced precisely because it gave rise to an intense collective task towards its definition, stabilization and clarification: genres and forms, and, of course, concert programmes and concert hall repertoires, as well as less institutionalized variables, such as the features of tempi, alternating moments of tension and relaxation, typification of instruments and timbres, postures and expressions expected from soloists, and so on. By contrast, this partial list suggests the strange and fragile position occupied by those other more synthetic but less precise words that seek to capture the 'spirit' of what is happening and not to delineate the elements that make it up. They are both more important and less self-confident, as if describing all at once the heart of a phenomenon and the impossibility of achieving it. 'If you have to ask what jazz is, you'll never know', Louis Armstrong reportedly said. Soul or inspiration, feeling or virtuosity, saudade or 'blue note', prodigy or genius: while vocabulary changes with genres and musical styles, there is still a persistent need to pin down things beyond what is describable, and to put a word to those utterly unspeakable but decisive feelings. What we face here is the specific problem raised by these empty words that try to designate without designating, to indicate a question more than to mean anything whatsoever. ${ }^{8}$

\section{A Truth of Mechanics?}

While words such as swing or genius create a strong polarity between the letter and the spirit and between technical means and emotion, reinforcing this dualism, the paradox of virtuosity is that it aims to posit something about the 'spirit of skill'; it suggests a part of the truth that exists in mechanics. Far from opposing art and its means, it speaks of what the art itself could be from within its means, or making the means an art itself. It thus recovers the older sense of the word art, which verges on technique: art is always in the art of making, in the art of doing, something which magicians and clowns remind us of in performances that are primarily a sideshow. There is yet another more historical path that emerges here: this involves a virtuosity that, in opposition to the aestheticism of art, sustains the skill and craftmanship that is central to a performance. Art is a bodily gesture, and not just a mental projection or the expression of one's soul. In their oppositional directions, such dualistic formulae nevertheless miss what, in my view, the word virtuosity signifies: as I have already said, it is not as viable to isolate, separate or analyse performance trends as to hedge one's bets on their secret junction; playing the game of an unlikely rapprochement in the alchemy of the moment.

'To hide art by very art'. ${ }^{9}$ One of the first tensions worth noting indeed draws the issue of virtuosity close to that of improvisation, of risk taking, of being on stage; all these unevenly mixed ingredients, taken together, are what constitute the power of a performance. This relationship is a reminder of an aspect I have only touched on so far; a strong constraint that weighs on the bliss of the sequences of breathtaking virtuosity as they determine the success

\footnotetext{
${ }^{8}$ Jankélévitch (1961).

${ }^{9}$ The formula is by Rameau, in the letter he wrote in 1827 to Houdar de La Motte in order to convince the playwriter to write a libretto for him (it has been published in Le Mercure de France, 1865).
} 
of a brilliant improvisation: the fact is that they move forward only when they are slightly concealed, producing their effect when they seem to arise from a moment. ${ }^{10}$ If they hint at too much sweat, if they seem too prepared, and if they give the impression of having been heard a hundred times, they rapidly lose their charm, dwindling to nothing short of pointless exercises. Furthermore, the speed that defines virtuosic quality is bound to be looked down on as soon as one becomes afraid of affording it too much importance: while it has little else to show but its acts to prove its point, these acts themselves are subject to assessments that cannot be grounded.

\section{Olympia the Doll ...}

This prerequisite is severe; it forces virtuosity to break away from both the work that makes it possible and from the device that makes it attractive. One must receive it without entirely seeing it for what it is; the audience must not be overtly sensitive to the staging required by the performer. The problem is not so much the tedious side of a performance, which offers itself as fluidity incarnated, but rather its predictable aspect - seeing it from a mile away with the performer's intention of knocking the socks off the receiver. One can observe strong but risky contiguities, which virtuosi sustain. In particular, two characters emerge as natural friends:

1. Magicians, from whom virtuosi borrow many of their stage tricks, learn to know the ropes as well as peddlers' tricks, which are so good at capturing attention; classical interpreters draw from tavern fiddlers, balalaika players, accordion dance musicians or bar pianists threading their devilish ragtimes. In so doing, they find out things that go against everything they have ever learned - the glamorous side of scales and arpeggios played one after the other on simple and repetitive canvasses at a frenetic pace, faster and faster, triggering the frenzy of the audience itself, quite unable to say whether it is carried away by the flood or whether it enjoys pretending to believe it is being carried away; these two states are hardly distant from one another!

2. Automatons, whose virtuosi seem to seek mechanical perfection while fearing to be mistaken for being automatons - because the only appeal in the way they play resides in the fact that they perform features one might think only a machine could do, whereas they are human beings like you and me.

There is no more brilliant idea than that of Offenbach's librettists to stage a double play in the first of the Tales of Hoffmann with the doll Olympia: the confusion between a diva and an automaton is first used literally in the scenario. The poor Hoffmann is in love with the singer whose virtuosity he admires without knowing what everyone else knows - that she is only a doll. However, this confusion is also used by Offenbach metaphorically quite precisely because Olympia is played by a real singer, whereby her very skilful 'performance' is applauded as the performance of an artist imitating an automaton, and not as that of a doll imitating an artist! In the background, even deeper in terms of metaphor, Offenbach is actually engaged by bitterly criticizing the prowess of coloratura singing with a dose of talent and humour: constantly playing around with crossing the boundaries between the automatic aspect and the virtuoso aspect of the soprano's shrill notes, he presents the audience with a real bravura, which indeed exists in all coloratura-sopranos' repertoire (at least for those who are able to deliver it). And in the same gesture, a comic parody of these operatic arias - a parody whose plot entirely rests on the mechanical and artificial character

\footnotetext{
${ }^{10}$ See the issue of Tracés (2011) dedicated to improvisation.
} 
of these arpeggios that shatter before starting off again once the key in the doll's back has been rewound. Finally, with no solution of continuity besides that of the robotic qualities of the virtuoso doll, the stage reveals its magician, and evil one at that. For behind the doll there is its creator, the shady magician who amazes the complicit audience, deceiving the all too poetical Hoffmann. ${ }^{11}$

\section{Rascher und rascher ...}

Velocity, a path of large intervals within very short periods of time, escalations of ornamentation and variations, notes doubled an octave apart ... those processes, fully exploiting the characteristics of each instrument or its limits, demonstrate virtuosity that is necessary for its display. They also constitute what reveals vanity, quickly toppling it into its opposite, pointless acrobatics, soulless agility. The case of classical music is interesting in that it has greatly increased in tension, in terms of this ambivalence of virtuosity; whereas popular music has managed it with good nature and indulgence: 'come on, minstrels, just play for us!' The Romantic aesthetic expression of the subject, however, amplifies the discomfort aroused by virtuosity, whose illusionist facet articulates poorly in a quest for truth in works that are demanding. The obvious use of artifice, which was no problem as related to classical aesthetics, ${ }^{12}$ has to be thoroughly reworked; it has to be contained in order to be made endurable. Yet, once it is perceived as being 'dedicated' to art, is virtuosity a protective barrier against its excesses, or a comfortable denial behind which one can, without scruples, give oneself up to it? It is difficult to decide. But for sure, it was at the very moment the theme of the necessary subjection of virtuosity became commonplace that it took on far unknown dimensions, particularly through the development of the modern piano in the early nineteenth century: that was the moment when in high society circles and on the stages all over Europe Czerny, Moscheles, Chopin, Thalberg, Alkan, and eventually Franz Liszt (the one who was to become the very epitome of an evil and brilliant virtuosity) took their places.

In depending on genres and instruments, it seems to me that these Romantic artists used two different approaches to deal with virtuosity. The first involves mainly the aesthetic. The contempt that Schumann could not help feeling towards Liszt - despite the generous support Liszt gave him - perfectly exemplifies this attitude. Schumann, the man for whom there were no laws in art other than those of morality, ${ }^{13}$ had a hard time coping with exhibitionism, seduction, taste for popular success, pursuit of the brilliant effect, indeed all the features he perceived in Liszt's character and in his music. The problem is far from simple, because it is not a matter of pushing away the difficulty of writing and performing works, which composers such as Chopin or Schumann did take to an extreme as much as Liszt (barely had Schumann written Als rasch wie möglich ${ }^{14}$ at the beginning of a piece than the same Schumann had added, a few staves later, Rascher und rascher ...), but rather it is to obey to the letter the absolute injunction of 'may the interpreter serve the work, not the work serve the interpreter'.

\footnotetext{
${ }^{11}$ Musical abstracts illustrating the case can easily be found on internet (they are inserted in Hennion 2011). Here, see for instance, Natalie Dessay's performance in 'Les oiseaux dans la charmille' at the Bastille Opéra in 1992 (staging by Roman Polanski).

${ }^{12}$ To whom artifice, on the contrary, is the most direct path towards Nature (Kintzler 1983).

${ }^{13}$ Cf. in the 'Musical Rules at Home and in Life' he wrote as a Preface to his Album für die Jugend for the piano (1848):

'The moral laws are also those of Art'.

14 'As fast as possible.'
} 
Declined in a thousand ways, this rhetoric of the means and the goal - or for that matter the master and the slave - becomes an indispensable topos when it comes to virtuosity. Arthur Rubinstein used it cunningly while reaping all the benefits of fame and success, repeating 'with modesty' that performers only had talent while composers had genius. This reminder rapidly sounds like a somewhat handy alibi, a position with no opposition that each and every one ensures he occupies himself while accusing others of giving in to the easy way. Nevertheless, this complex topic cannot be reduced so simply: at the very heart of composition, it refers to a very strong requirement - in the great Romantics' works - to that of a maximum coherence among all musical parameters. This is the first response of classical music to virtuosity, and however difficult they may be, Schumann's pieces or, in a less unambiguous way, those of Chopin ${ }^{15}$ are not virtuosity pieces.

So, what does this mean? I have no intention of taking this statement for granted, but rather to see if it leads to the possible illustration of technical differences in the form of pianistic writing itself. The idea has a relevance, even though I will not endeavour to prove or develop it in this context. It is that which the word composition, taken literally, expresses well: the opposite of a virtuoso piece is not necessarily an easy piece, or a work that foregoes exploiting the resources of techniques, but more an integrated piece, a piece whose various elements closely respond to each other and constitute one another.

It is this vital distributed aspect of music that makes inappropriate the vocabulary of virtuosity. However, this vocabulary can be deployed without embarrassment in a musical space where, on the contrary, the variables are clearly separated: an easily recognizable melody on which one can make all imaginable variations (plus a few others ...), a fixed harmonic grid on which one can improvise, a basic rhythm on which, say, Liszt could indulgently superimpose chromaticisms and demisemiquavers. Referring to Bach and Beethoven, Schumann would often insist that a melody is much more than what one can imagine: in more modern terms, one might say that to him, a melody is indeed distributed between (and no longer on) harmony, rhythm, figures that respond to one another. Conversely, harmony or form are not separable, but arise in successive layers by amplification to constitute one another and to com-pose one another: then there is no place any longer for the left hand droning an Alberti bass or striking its chords while the right hand spins in all directions! To say it in other terms, there is no longer a way to isolate a virtuoso line from its harmonic well-established framework, nor to hear it as the ornate variation of a given theme. In my opinion, this is precisely what undermines the idea of virtuosity, both under the composer's pen and in the amateur's ear. ${ }^{16}$

All said and done, this should not force one to be fooled by art history, which is constantly rewritten ex post like the long and difficult path towards the demands, purities and autonomies that aesthetic conformism has become. The idea is only to note how, as ideals, this ascetic, puritan repression of effects for effects had an effect, which, in turn, deserves to be recognized and analysed: ideals such as these have made possible the invention of a new language, characterized by coherence, by maximum integration that, in

\footnotetext{
${ }^{15}$ Eigeldinger (2000).

${ }^{16}$ To get a musical idea of the point, one can compare György Cziffra playing Liszt's Hungarian Rhapsody No. 3, and Martha Argerich in the ending of the third movement of Schumann's Fantasy in C major Op.17, which is very difficult not because of Liszt's lines, but because of everything occurring at once: a very fast and repeated rhythm jostling large arpeggio chords with both hands . The same 'à la Schumann' non-virtuosic virtuosity can be heard in 'Aufschwung', his Phantasiestucke Op.12 No. 2, and also in pieces by Chopin, such as the Study Op. 25 No. 11 in A minor, for instance played by Sviatoslav Richter. Chopin is of interest because he is somewhere between Liszt and Schumann: if there is obviously a clear opposition between chords and lines as in Liszt, his lines are closely linked and stress the percussive power of chords, which are not of the sort 'in' which twirling passages can be played.
} 
depriving virtuosity of much of its relevance, shifts the issue towards that of the overall difficulty of interpretation. The more popular or hedonistic aesthetics that these stringent requirements have repressed have no need to be defended, given their success. But neither can they be reduced to easy exploitations of existing processes. They also have to be elaborated through multiple channels. Incidentally, the continuities between art and popular musicians are striking as regards this matter. Virtuosity itself is so aligned with technical excellence that, when pursued, it never goes very far away. In the case of one of the more 'serious' composers, Brahms, one never ceases, for instance, to hear the gypsy accents of the violin, which the skill of classical quartets had managed to erase and disembody till nothing was left but a heavenly voice. Conversely, when Ravel methodically runs counter to the canons of Modernism, when he rehabilitates waltz, descriptive music, programmes and the 'gypsy' violin (inadvertently reasserting the value of virtuosity), it would be problematic to infer that his only aesthetic concern lies in the pleasure of impressing his public.

\section{'Vissi d'arte'}

There is a second way that classical musicians accommodated virtuosity that I wish to mention. As early as the nineteenth-century, well before the artists of the twentieth century's ironic or iconoclastic posturing, Romantic composers were able to turn to other means than pure aesthetics to confine the virtuosity, to exploit it without allowing it to decimate the music: and the most important approach, in tandem with the previous, involved a resistance to this 'virtuosity-effect' by opposing the mixed richness of emotion, the never-ending quest for the expression of feeling, as in opera, rather than the uncompromising autonomy of a work. A priori, as a virtuosic development material, the voice had every reason to compete with the violin or the piano. It did not deprive itself of so doing. ${ }^{17}$

Vocalizations, arpeggios, sostenuti, endless ornaments and cadenzas, singers rival each other in skill, stripping the works of composers who are powerless in limiting their excesses: here we are again facing the very words of the argument about virtuosity. However, in contrast with chamber or orchestral music, opera has never been under the influence of autonomous aesthetics, of which it is the absolute antithesis. ${ }^{18}$ Wagner's revolutionary pretensions, which were to favour his Modernist annexation, targeted a total art, which was quite different: only a deaf person would not to hear the heterogeneous diversity of the effects that saturate his writing, both on stage and in the pit. As for other composers, from Mozart to Debussy, from Gounod to Verdi, from Mussorgsky to Strauss or to Berg, they all instinctively accommodated opera within another space, which consistently reversed the representations of 'pure' music: a mixture of ambiguity, entertainment and dance, where the bodily pleasure of voices, projection and identification eroticized characters, the place where the plot, the stage play and the words attempt, with variable success, to marry singing with the orchestra. ${ }^{19}$ One can understand that such an unlikely union can only last if it is armoured with conventions. The Modernists themselves, fascinated by this anti-model that opera

\footnotetext{
${ }^{17}$ There is a profusion of examples here. See e.g. Rossini's 'Una voce poco fa' ('A voice has not much power'!) in the Barber of Seville: 65 years before Olympia, already a 'mise en abyme' lesson, Rosina's contest, sung for instance by Maria Callas in 1959. Or, again in the Barber, 'Largo al factotum', for instance by Thomas Hampson in 1992, for Rossini's 200th anniversary, in which he acts as a clown and adds notes.

${ }^{18}$ Fulcher (1987).

${ }^{19}$ Hennion (2007a).
} 
shows them, have repeatedly promised its death, before rushing into its arms at the first opportunity. ${ }^{20}$

And yet, also on this stage - a stage that is so far away from purifying asceticism and from art for art's sake, so conducive to spectacular excess - virtuosity has had to surrender. The never ending fragility of Norma's melodic ascent, the spellbinding power of Isolde's complaint, Carmen's sarcastic accents or La Traviata's bloody tears: while requiring from singers an inordinate performance, they hardly evoke the idea of virtuosity. Just as Chopin's Etudes, straight as an arrow despite their chromatic descents, or Schumann's Fantasy, whose rhythm is impossible to maintain, it is not so much that these lyrical summits stand beyond the diagnosis of virtuosity, but rather that they make it obsolete, useless, that they outstrip it from itself. But they do it in ways that are contrary to those of the great Romantic piano composers, not by the rigour and coherence of a musical form, but through the tentative mobilization of an emotion that is both intimate and collective, leaning on all the age-old techniques of performance: the mythical narrative, the drama of love and death, the exposure of bodies and the painful tension of extreme performance. Then there is the impossibility of love profiled by the backdrop of a tragic chorus: from Orfeo to Lulu, we might ask which opera is the exception to the process? At the same time, this ageless canvas, this endless $d a$ capo is an opening that has no boundary, no background and no horizon. Is it still even music? What pleasure is there in hearing a long, shrill note, to listen to a tune for the thousandth time that one owns ten versions of, or to observe the accents and impetus of a voice with a magnified potential through extraordinary technical developments? Who can say what that 'emotion' exactly comprises - another of these intermediate words impossible to define.

\section{A well-tempered virtuosity}

Nothing prevents an amateur liking both nineteenth-century piano sonatas and Romantic operas. The abstraction of a musical language pushed to its limits, and the sensual and projective ambiguity of the great lyrical machine, do not exclude one another. Moreover, these genres are all laden with a thousand virtuoso feats. Nevertheless, in both cases, virtuosity has been pushed back to the fringes, or confined to a closely observed enclosure. While virtuosity is certainly present, the genre unfolds against it in a double sense, where the genre in question both leans against and opposes virtuosity. This founding gesture, which defines virtuosity by default after having stripped it of any aesthetic value, also disqualifies it in other genres, as if by contamination. Two centuries of Romantic then Modernist aesthetics have managed to turn it into some kind of primary background for our musical and dramatic instincts, which any self-respecting artistic practice has a duty to surpass.

My point is that there is no reason for this to be so. It is quite possible to elaborate on the rigour of aesthetics, not in spite of virtuosity, but for it. By not relegating virtuosity to the margins of the definition of quality, but by making music arise from its effects, by starting from the virtuoso gesture to make it express what it can bring. This is worth repeating, I think, with an entire aesthetic tradition in mind: our frayed vision of virtuosity is not a necessity; it is first and foremost the effect of the dualistic vision of Romanticism, further amplified by Modernism. The more we adamantly oppose idea and matter, means and ends, mind and body, the more we impose a dichotomized musical space; between art and

\footnotetext{
${ }^{20}$ Hennion (2007b).
} 
technique, between the truth of an inner feeling and the artifice of the notes that express it. On the one hand, the work bequeathed by the genius; on the other hand, a humble servant who deciphers the composer's mysterious 'intentions'. This entire topology, which is so paradoxical when talking about the art of playing and performing, goes against a conception that is, instead, connected, continuous, articulating gesture and effect, confounding the work and its interpretation, unable to dissociate means and ends, and refusing to separate body and emotion. Yet, is that not that exactly the positive programme that one can build virtuosity upon? The assumption is not at all crazy; rather, it's more a reassuring return of the repressed. When playing, the majority of classical performers continue to live what they deny, and keep connecting through their bodies what their minds believe they have severed. What they seek is the flexible, subtle articulation of a gesture that is to be made over and over again; this strives towards a music that is never there, which is far from the blinding clarity that too aptly separates the 'score ${ }^{21}$ from its 'interpretation'.

\section{Giant Steps}

Which brings us to aesthetics. What happens if we leave the temples of classical music? Just think of flamenco, open-air dance music and the intoxication of accordions, or African drums: an intense emotion may occur - not beyond the prowess of the bodies, but within them. Flamenco is nothing but virtuosity, that of fingers on strings, that of the improvised melisma of a husky voice flying away and stroking the breaks of the rhythm, that of tapdancers' heels slamming and speeding up, that of busts and bellies that swirl and arch, constantly bounced from the broadest movement to immobility lying in wait, and that of hands carving the air. Everything concerns the body in terms of deftness and difficulty, but who would have the idea of turning away from this physical tension to search for the source of the pleasure, and of looking instead for it in the intimacy of an inner soul or in the absolute beauty of a work? The moment, the place and the performance are there at centre stage. Music and emotion are but the same words made to express a single event, that which gives the present its density.

My purpose in referring to flamenco is not to isolate a genre, which, like Asterix's little Gallic village resisting the general invasion of form and pure emotion, would have preserved the rare cult of the virtuoso gesture, but rather to suggest from real examples that an aesthetic of virtuosity is possible; a positive, contemporary aesthetic that creates new worlds rather than an aesthetic by default. And this would not be to assign it exclusively to one music rather than another: but instead, to regard it as surreptitiously adhering to the noblest, the most sublime and the most sensitive genres. But dwelling on the flamenco may be too easy an example to prove the possibility of a bodily aesthetic: does the flamenco not typify the music of 'the other'? one might say that I am just extending the dualism I wish to oppose between 'them' and 'us', ${ }^{22}$ between the popular and corporeality of popular music on the one side, and classical music, made of written works, on the other. Everyone seems content now to grant exoticism opposite qualities to those championed by the Christian West - the power of trance, the vitality of rites, the mobility of bodies, the intensity of a people, as reflected in music. Is the unsettling question really about wondering whether this 'other' music is beautiful? Who still doubts it? But what if this music did do what scholarly music does:

\footnotetext{
${ }^{21}$ The music score is, so revealingly, named 'partition', in French!

${ }^{22}$ Geertz (1988).
} 
what if 'other' music were also constructing a work of art, and were doing so by stressing even more the etymology of the word - working at having the 'art work', so to speak?

To provide a positive answer, albeit without concluding, I want to make my point by turning to jazz - a genre that is partly other, at least when compared to the classical tradition. Yet it is an 'other' with its origins at the heart of our culture, and not its periphery. 'Mozart played by blacks', people claimed when referring to ragtime. This is probably what resulted in jazz becoming a concentration of divergent forces. Jazz could be considered as representative of African Americans, and under the aegis of an illusory radicality, filed a few decades later on another shelf in the store of folklore or at the museum of ethnicities. Instead, jazz has incorporated all the ingredients of modern Western music, both in its forms, harmonies and instruments, and processes of mediation. Rapidly, jazz became radio and recorded music rather than music from plantations. It was black music played for white men, first for their entertainment, then as music approved of by the Europeans. ${ }^{23}$ Its accelerated history became the result of a succession of renunciations (of whatever could reduce it to a particularistic music) and adoptions (of anything that could integrate it into time and space). It only remains identifiable through a few, minimal but decisive traces: the blues, the improvised choruses, a frenetic pace.

Returning to the central theme of this chapter, I would like to suggest that jazz may have invented something unique due to its intrinsic qualities: like classical music through its material, its format, its performance, but with only one small entity that makes all the difference - its emphasis on performance, not on the work. ${ }^{24}$ This has come about through a historical shift resulting in its transposition and transformation into a contemporary mould. Bebop is not flamenco precisely because of this internal resumption: it is played and dressed up in a Western manner. Moreover, it meets the requirement of the clean aesthetic carved out by Western music, concentrating on itself and aiming at the production of differentiated works. In this sense, it is obvious that jazz is a form of modern Western music, and not a traditional or ethnic music. Nor is it a popular music with a common cultural or social identity fixed by stable codes. Virtuosity in jazz is neither the proof of a collective performance made indistinct by the body through dance and ritual in the form of entertainment, nor is it the basic starting point from which music evolves. Let me say things again in a different way: whereas the mapping of the music of Western culture is granted by original scores, jazz privileges the act of playing, of engaging through exhilarating pleasure virtuoso sequences of scales and chords, and, as with flamenco, it is located in the here and now, in the collective heat of a public that is beside itself with joy. Yet, unlike flamenco, its sole concern is in the making of music: ${ }^{25}$ for jazz is a dedicated Western style - it has not so much rid itself of the notion of work as it has emphasized the work as being the performance itself. Take Coltrane, an artist in the modern sense of the word: he does not play 'jazz', but rather takes the risk of offering $a$ separate version of the standard each time he performs.

The issue I leave open is: in listening to Giant Steps (what a nice summary of the history of jazz, that title is!), what I hear is an aesthetic of virtuosity - a formula that has a meaning only provided one gives equal weight to both words. Jazz is music that has succeeded in making virtuosity itself the very subject of aesthetics.

\footnotetext{
${ }^{23}$ Gumplowicz (1991).

${ }^{24}$ Berliner (1994).

${ }^{25}$ Or 'being music', to say it in a perhaps more accurate way.
} 


\section{References}

Berliner, Paul F. (1994) Thinking in Jazz. The Infinite Art of Improvisation (Chicago: The University of Chicago Press).

Butler, Judith (1997) Excitable Speech: A Politics of the Performative (New York: Routledge).

- (2005) Giving An Account of Oneself (New York: Fordham University Press).

Eigeldinger, Jean-Jacques (2000) L'univers musical de Chopin (Paris: Fayard).

Frith, Simon (1996) Performing Rites. On the Value of Popular Music (Cambridge: Harvard University Press).

Fulcher, Jane F. (1987) The Nation's Image. French Grand Opera as Politics and Politicized Art (New York: Cambridge University Press,).

Geertz, Clifford (1988) Works and Lives: The Anthropologist as Author (Stanford, CA: Stanford University Press).

Gumplowicz, Philippe (1991) Le roman du jazz: première époque, 1893-1930 (Paris: Fayard, 1991).

Hennion, Antoine (2007a) 'Rewriting History from the Losers' Point of View: French Grand Opera and Modernity', in V. Johnson, T. Ertman and J. Fulcher (eds.) Opera and Society (Cambridge, Cambridge University Press), pp. 330-50.

- (2007b) 'Étudier le modernisme ?', in D. Colas et al. (eds.) Musique, esthétique et société au XIX ${ }^{e}$ siècle. Mélanges en l'honneur de Joël-Marie Fauquet (Liège, Mardaga), pp. $19-31$.

- (2011) 'Aussi vite que possible ... La virtuosité, une vérité de la performance musicale?', in E. Grimaud, G. Jones, V. Stoichita (dirs.) Ateliers du LESC, 35, pp. 1-23, put on line at http://ateliers.revues.org/8764 on June 10, 2011, accessed on November 18, 2011.

Jackson, Shannon (2004) Professing Performance: Theatre in the Academy from Philology to Performativity (Cambridge: Cambridge University Press).

Jankélévitch, Vladimir (1961) La musique et l'ineffable (Paris: Colin).

Kintzler, Catherine (1983) Jean-Philippe Rameau. Splendeur et naufrage de l'esthétique du plaisir à l'âge classique (Paris: Le Sycomore).

Leppert, Richard and McClary, Susan (eds.) (1987) Music and Society: The Politics of Composition, Performance and Reception (Cambridge: Cambridge University Press).

Rouget, Gilbert (1980) La musique et la transe. Esquisse d'une théorie générale des relations de la musique et de la possession (Paris: Gallimard).

Schumann, Robert (1848) 'Musical Rules at Home and in Life', Preface to Album für die Jugend for the piano.

Schechner, Richard (2002) Performance Studies: An Intro (Oxford: Routledge).

Scott, Derek B. (1989) The Singing Bourgeois: Songs of the Victorian Drawing Room and Parlour (Milton Keynes: Open University Press). (Second edition, Aldershot: Ashgate, 2001.)

- (2008) Sounds of the Metropolis: The 19th-Century Popular Music Revolution (in London, New York, Paris, and Vienna) (New York: Oxford University Press).

Sudnow, David (1978) Ways of the Hand. The Organization of Improvised Conduct (Cambridge, MA: The MIT Press).

Tracés (2011) 'Improviser' (special issue on improvisation), Tracés, 18, 2010(1).

Whiteley, Sheila, Andy Bennett and Stan Hawkins (eds.) (2004) Music, Space and Place: Popular Music and Cultural Identity (Aldershot: Ashgate, 2004). 